\title{
IMPLIKASI PEMBERITAAN LESBIAN GAY BISEKSUAL TRANSGENDER (LGBT) PADA AKTIVITAS LEMBAGA SWADAYA MASYARAKAT
}

\author{
Denada Faraswacyen L. Gaol \\ denada.faraswacyen@budiluhur.ac.id \\ Prodi Hubungan Internasional FISIP \\ Universitas Budi Luhur
}

\begin{abstract}
ABSTRAK
Penelitian ini bertujuan untuk mengetahui implikasi pemberitaan LGBT pada aktivitas LSM Arus Pelangi, Yayasan Inter Medika, dan Yayasan Srikandi Sejati dengan menggunakan metode studi kasus, pengumpulan data primer yaitu wawancara dengan key informan dari ketiga LSM terkait dan dianalisis dengan Teori Disonansi Kognitif. Ramainya pemberitaan terutama yang berkaitan dengan perlakuan negatif yang diterima oleh LGBT memunculkan beberapa bentuk pembelaan dan perlindungan atas nama kemanusiaan dan HAM. Hasil penelitian ini menunjukkan bahwa kaum LGBT yang dianggap tidak sesuai dengan budaya dan norma sosial yang berlaku di masyarakat selayaknya mendapat dukungan sosial. Dukungan sosial (social support) diberikan oleh Arus Pelangi memiliki program kampanye sosialisasi hak-hak dasar manusia dan penghilangan tindakan diskriminatif pada kaum LGBT dan advokasi yaitu advokasi kasuistik dan advokasi kebijakan public. Advokasi kasuistik merupakan kegiatan penanganan hukum kasus-kasus yang menimpa kaum LGBT baik bersifat litigasi maupun non-litigasi. Advokasi kebijakan publik merupakan rangkaian upaya hukum terhadap semua kebijakan pemerintah yang diskriminatif misalnya penolakan terhadap Rancangan Undang-undang Anti Pornografi dan Pornoaksi (RUU-APP). Yayasan Inter Medika dan Yayasan Srikandi Sejati yaitu LSM yang berfokus pada pendampingan atau penyuluhan kesehatan seperti penyakit menular seksual dan penanggulangan penyebaran virus HIV/AIDS pada kaum LGBT dengan bekerja sama dengan Pemprov DKI Jakarta dan beberapa rumah sakit di Jakarta.
\end{abstract}

Kata kunci: Pemberitaan, LGBT, LSM

\section{ABSTRACT}

This study aims to determine the implications of LGBT news on the activities of NGOs as follows: Arus Pelangi, Inter Medika Foundation and Yayasan Srikandi Sejati by using the case study method, with primary data collected through interview with key informants from the three NGOs and analyzed with the Theory of Cognitive Dissonance. Numerous coverage mainly those telling the negative treatment towards LGBT triggers various forms of defense and protection in the name of humanity and human rights. The results of this study indicate that LGBTs who are considered incompatible with the cultural and social norms prevailing in society have the rights to receive social support. Social support provided by Arus Pelangi covers program campaigning on the socialization of basic human rights and the eliminaton of discriminatory action on LGBT and advocacy which are the casuistic and the one on public policy. Casuistic advocacy is a legal 
activity on cases of litigation and non-litigation affecting LGBT. Advocacy on public policy is a series of legal actions against all discriminatory government policies, for example is the rejection of the Bill on Anti-Pornography and Porn Actions (RUU-APP). Inter Medika Foundation and Yayasan Srikandi Sejati are NGOs that focus on health assistance or counseling, for examples are on issues of sexually transmitted diseases and prevention of the spread of HIVIAIDS among LGBTs, by having cooperation with the local government and several hospitals in Jakarta.

Key words: News, LGBT, NGOs

\section{PENDAHULUAN}

Isu lesbian, gay, biseksual, dan transgender (LGBT) dari tahun ke tahun terus berkembang tidak terkecuali di Indonesia. LGBT di Indonesia setidaknya sudah ada sejak era 1960-an dan terus berkembang pada dekade 80-an, 90-an, meledak pada era milenium tahun 2000 hingga sekarang (Jurnalis, 2016). Pada era 1960-an, dikenal dengan Sentul dan Kantil, kini sebutannya adalah Buci dan Femme. Cikal bakal organisasi dan advokasi LGBT di Indonesia sudah berdiri lama. Salah satunya organisasi jadul bernama: Hiwad, Himpunan Wadam Djakarta. Wadam, wanita Adam, mengganti istilah banci dan bencong. Namun, organisasi Wimad diprotes MUI. Pada 1982, pelaku homo mendirikan Lambda Indonesia. 1986 berdiri Perlesin, Persatuan Lesbian Indonesia. Pada tahun yang sama, berdiri juga pokja GAYa Nusantara, kelompok kerja Lesbian dan Gay Nusantara (Akbar, 2016).
Menurut Alumni Kriminologi Universitas Indonesia (UI), Maman Suherman dalam acara Polemik Sindo Trijaya bertajuk LGBT, Beda tapi Nyata, pada 20 Februari 2016 di Jakarta, Kaum LGBT di Indonesia bukan polemik baru yang muncul di Indonesia. Keberadaan LGBT di Indonesia mulai terasa sejak 1973. Kala itu kemunculan mereka di publik berbarengan dengan film berjudul "Akulah Vivian" yang bercerita tentang kehidupan seorang transgender. Lalu diulangi oleh artis bernama Dedi Yuliardi Ashadi alias Dorce yang melakukan penggantian alat kelamin (Ramdhani, 2016). Sosiolog Universitas Islam Negeri (UIN) Syarief Hidayatullah, Musni Umar, mengatakan eksistensi kaum LGBT dapat dirunut sejak Orde Baru. Meningkatnya kesejahteraan masyarakat dan modernisasi mendorong eksistensi kaum LGBT di Indonesia karena mengenyam pendidikan, mereka mendapatkan banyak terpaan informasi dan budaya. Salah satu terpaan terkait dengan orientasi seksual yang 
mengarah kepada menyenangi sesama jenis (Ramadhan, 2015).

Merebaknya perkembangan LGBT di Indonesia berimbas pada berdirinya beberapa Lembaga Swadaya Masyarakat (LSM) sebagai kelompok pendukung.

Dalam beberapa tahun awal 1900-an berdiri berbagai organisasi di Bandung, Jakarta, Pekanbaru, Denpasar, Malang dan Makassar. Para lesbian dan pria transgender juga berusaha mengorganisir kelompoknya di Jakarta, Makassar dan Singaraja. Chandra Kirana, yang merupakan kumpulan lesbian di Jakarta, membuat majalah sendiri, yaitu Gaya Lestari, yang selama sekitar dua tahun terbit sebagai sisipan dalam majalah GAYa NUSANTARA.

Dari beberapa LSM yang mendampingi kaum LGBT, salah satunya adalah LSM Arus Pelangi yang concern mendampingi dan melakukan fungsi advokasi pada kaum LGBT. Aktivitas LGBT dan beberapa organisasi pendukung yang memberikan pendampingan dalam bidang kesehatan, hukum, dan lain-lain semakin banyak diberitakan seiring dengan banyaknya reaksi yang muncul baik pro maupun kontra. Puncak pemberitaan yang cukup banyak menyita perhatian khalayak adalah pemberitaan legalisasi undangundang pernikahan sejenis oleh Mahkamah
Agung Amerika Serikat pada 26 Juni 2015. Mahkamah Agung (MA) Amerika Serikat melegalkan pernikahan sesama jenis di 50 negara bagian melalui keputusan bersejarah pada Jumat (26/6/2015) waktu setempat (http://internasional.kompas.com/read/2015/ 06/26/23073761/Mahkamah.Agung.Amerik a.Legalkan.Pernikahan.Sesama.Jenis).

Sedangkan cuplikan berita lainnya Jumat 26 Juni 2015 waktu Amerika Serikat (AS), sejarah nan kontroversial tercipta di Negeri Paman Sam. Negeri adidaya itu resmi melegalkan pernikahan sejenis. AS bukan negara pertama yang mengesahkan hukum UU kontroversial ini. Ada lebih dari 20 negara yang melegalkan hal tersebut sebelum Amerika membuat keputusan yang menggemparkan warga dunia, sebenarnya keputusan melegalkan pernikahan sejenis sudah ada sejak 2001 dengan negara Belanda yang menjadi negara pelopor pelegalan pernikahan sejenis (http://global.liputan6.com/read/2260668/pe rnikahan-sesama-jenis-dilegalkan-di-23-

negara-ini). Berita sejenis juga dimuat dari perspektif yang berbeda yaitu pengakuan oleh PBB tercatat telah ada 22 negara dari 204 negara yang telah diakui secara de facto oleh PBB yang melegalkan pernikahan sesama jenis secara penuh di seluruh wilayah negaranya 
(http://lifestyle.sindonews.com/read/108285

5/166/daftar-negara-yang-melegalkan-

pernikahan-sejenis-dan-lgbt-1454594358).

Pemberitaan legalisasi undangundang tersebut dalam waktu singkat menyebar ke banyak negara tidak terkecuali Indonesia. Media massa berperan besar dalam menyebarkan informasi tersebut. Informasi tentang legalisasi undang-undang tersebut disebarluaskan melalui media cetak, media elektronik, dan media baru. Dalam waktu singkat khalayak menunjukkan reaksi beragam terutama melalui media sosial yang mereka miliki, seperti: penggunaan background profile picture di facebook berwarna pelangi dan \#LoveWins, sebagai bentuk dukungan, sedangkan yang menolak ditandai dengan \#DaruratLGBT. Pemberitaan tersebut tidak hanya menimbulkan reaksi pada individu dan masyarakat, tetapi juga berdampak pada organisasi yang concern terhadap LGBT baik organisasi pendukung maupun yang memberikan pendampingan dalam bidang kesehatan dan hukum seperti: LSM Arus Pelangi, Yayasan Inter Medika, dan Yayasan Srikandi Sejati yang berada di Jakarta. Berdasarkan uraian tersebut maka rumusan masalah dalam penelitian ini yaitu "Bagaimana implikasi pemberitaan Lesbian Gay Biseksual Transgender (LGBT) pada aktivitas Yayasan Inter Medika dan Yayasan Srikandi Sejati?

\section{TINJAUAN PUSTAKA}

\section{Teori Disonansi Kognitif}

Festinger (1957) menjelaskan bahwa disonansi kognitif adalah diskrepansi atau kesenjangan yang terjadi antara dua elemen kognitif yang tidak konsisten, menciptakan ketidaknyamanan psikologis. Hal ini didukung oleh Vaughan\&Hogg (2005) yang menyatakan bahwa disonansi kognitif adalah suatu kondisi tidak nyaman dari tekanan psikologis ketika seseorang memiliki dua atau lebih kognisi (sejumlah informasi) yang tidak konsisten atau tidak sesuai sama lain. Kognitif menunjuk pada setiap bentuk pengetahuan, opini, keyakinan, atau perasaan mengenai diri seseorang atau lingkungan seseorang. Elemen-elemen kognitif ini berhubungan dengan hal-hal yang terdapat dalam dunia psikologis seseorang.

Terdapat dua macam hubungan antarelemen (Festinger, 1957 dalam Shaw\&Contanzo, 1982) yaitu:

1. Hubungan tidak relevan (irrelevant), yaitu tidak adanya kaitan antara dua elemen kognitif. Misalnya: pengetahuan bahwa merokok buruk bagi 
kesehatan dengan pengetahuan bahwa di Indonesia tidak pernah turun salju.

2. Hubungan relevan, yaitu hubungan yang terkait sehingga salah satu elemen mempunyai dampak terhadap elemen lainnya.

Teori disonansi kognitif memiliki implikasi penting dalam banyak situasi spesifik. Festinger menjabarkan implikasi dalam keputusan (decisions), forced compliance, pencarian informasi (exposure to information), dan dukungan sosial (social support). Dari situasi tersebut dapat diketahui besarnya kekuatan disonansi.

1. keputusan (decisions): disonansi akan semakin kuat jika keputusan semakin penting dan jika ketertarikan dari alternatif yang tidak dipilih semakin besar. Contoh: munculnya disonansi keputusan yang diambil adalah perokok berat yang memutuskan untuk tetap merokok mengalami disonan ketika ia mengalami sakit kanker paru akibat merokok (hal negative dari akternatif yang dipilih) dengan hal positif yang akan ia dapat bila tidak merokok, yaitu sehat (alternative ditolak).

2. forced compliance: permintaan dari luar diri seseorang yang dipaksakan kepada seorang individu. Aplikasi terbatas pada permintaan public (compliance) tanpa disertai perubahan pendapat pribadi. Forced compliance mempengaruhi individu (perokok berat) yang membuat berhasil mengubah (berhenti merokok), mengubah perilaku atau ucapan yang terlihat mengubah opini dan keyakinan sebelumnya (merokok sembunyi-sembunyi), atau justru membuat mereka mencari dukungan sosial yang mendukung pendapatnya (bergabung dengan klub penggemar rokok)

3. pencarian informasi (exposure to information): disonansi menyebabkan pencarian informasi menjadi selektif, yaitu individu alan lebih mencari informasi yang menyebabkan konsonan dan menghindari informasi yang bersifat disonansi.

4. dukungan sosial (social support): berperan dalam mengurangi kondisi disonan. Disonansi kognitif akan dihasilkan oleh seseorang yang mengetahui bahwa orang lain memiliki opini yang berlawanan dengan opininya. Misalnya keyakinan atau pendapat masyarakat 
terhadap mantan napi. LSM Sahabat Andik berupaya memberikan dukungan sosial dengan memberikan opini positif terhadap mantan napi.

Berdasarkan teori disonansi kognitif tersebut dapat dijelaskan bahwa pemberitaan tentang LGBT di berbagai media massa berimplikasi pada aktivitas LSM dalam bentuk dukungan sosial (social support).

\section{Pemberitaan Media Massa}

Peran media massa sangat penting dalam membentuk arus utama opini pernikahan sejenis (sex same marriage). Serial-serial televisi di Eropa dan Amerika mulai memperkenalkan jenis hubungan percintaan sesama jenis sebagai suatu hal yang wajar, misalnya Sex and the City dan Game of Thrones. Media cetak pun turut mempublikasikan hubungan sesama jenis, sejak tahun 2004 ketika salah satu negara bagian di Amerika Serikat yaitu Massachusets melegalkan pernikahan sejenis, harian New York Times dalam kolom wedding, secara rutin menayangkan pasangan-pasangan homoseksual yang akan menikah sejajar dengan pasangan heteroseksual lainnya (http://www.nytimes.com/interactive/2015/0 6/26/us/changed-thinking-on-gaymarriage.html?_r=0, diakses 14 Mei 2016). Pernikahan desainer Joseph Altuzarra dengan Seth Weismen adalah contoh bagaimana media sangat mendukung pernikahan pasangan ini. Pernikahan itu masuk dalam kolom wedding New York Times, majalah mode kenamaan Vogue juga memberitakan foto-foto kedua pasangan tersebut.

Pemberitaan tentang LGBT di Indonesia sebenarnya bukanlah hal baru. Menurut Dede Oetomo, selama rentang 1981 - 1983, untuk pertama kalinya perdebatan tentang homoseksualitas menjadi wacana nasional, terutama ditandai dengan merebaknya beragam tulisan di berbagai media nasional, seperti: majalah Tempo, majalah Liberty, majalah Kartini, majalah Anda, majalah remaja Puteri, hingga harian Kompas. Dalam tulisannya yang berjudul Charting Gay Politics in Indonesia, Dede juga turut menulis bahwa kecenderungan media di Indonesia untuk meliput dan membahas tentang homoseksualitas dimulai sejak akhir 1970-an (http://www.rappler.com/indonesia/125064sejarah-gerakan-gay-indonesiahomoseksualitas).

Majalah Time merupakan salah satu media terkemuka di dunia, khususnya di Amerika Serikat. Time diterbitkan dalam beberapa edisi, edisi Eropa (Time Europe, dulu bernama Time Artlantic) diterbitkan di 
London. Time Europe dijual di Timur Tengah, Afrika, dan Amerika Latin (sejak 2003). Majalah Time menjadi salah satu media internasional yang secara jelas menjadikan sampul depannya dengan memberikan informasi terkait LGBT sebelum UU pernikahan sejenis di Amerika Serikat dilegalkan. Majalah Time terbit pada 8 April 2013 dengan judul "Gay Marriage Already Won", pada cover tersebut difoto secara close up berwarna hitam putih menampilkan pasangan sesama jenis yang sedang berciuman: Sarah Kate dan Kristen Ellis Henderson yang telah menikah selama dua tahun, dan di foto lainnya adalah Russell Hart dan Eric LaBonte yang sudah bertunangan (http://www.theglobeandmail.com/life/thehot-button/times-new-gay-marriage-coverstoo-in-your-face-or-symbols-oflove/article10491076/ diakses 14 mei 2016).

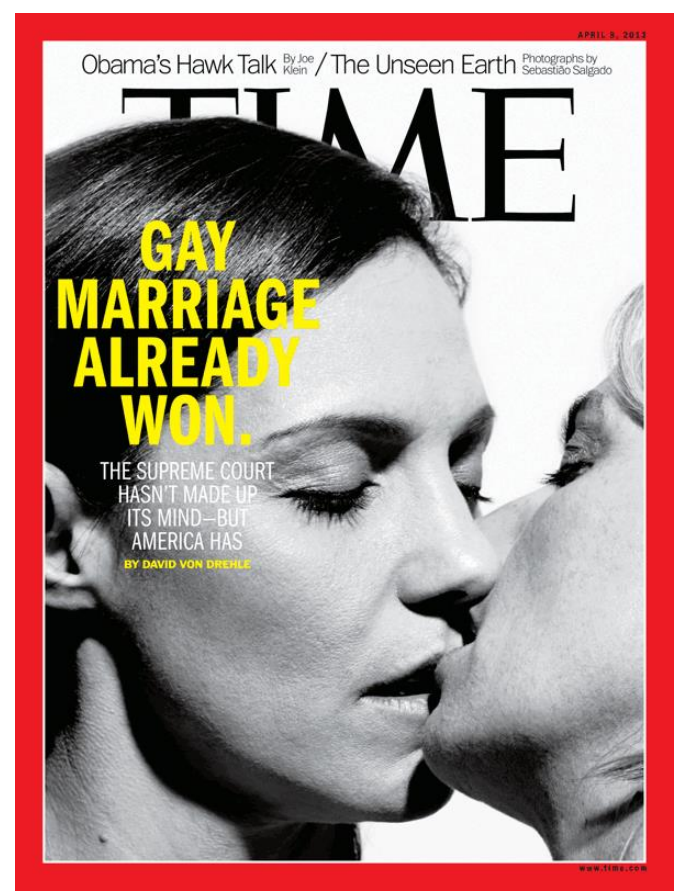

Gambar 1: Cover majalah TIME edisi 8 April 2013

Sumber: http://content.time.com/time/covers/0,16641 ,20130408,00.html

Sedangkan di Indonesia, media cetak yang secara jelas menjadikan LGBT menjadi sampul depan pada terbitan majalah Gatra. Artikel berjudul "LGBT Gaul" dari Sarlito Wirawan Sarwono, seorang psikolog Universitas Indonesia. Artikel ini dimuat di majalah Gatra yang bertajuk "Melawan Aksi LGBT di Kampus" (Edisi 4 - 10 Februari 2016) (http://www.gatra.com/fokus-berita1/185468-arus-lgbt-masuk-kampus. diakses pada 14 Mei 2016). Sarlito memaparkan dua tokoh dari kelompok LGBT Indonesia, 
yaitu Dorce Gamalama dan seorang mantan menteri pada masa Orde Baru. Melalui dua orang tokoh ini, penulis berargumen bahwa keduanya telah banyak berkontribusi bagi masyarakat sehingga sebagai bagian dari komunitas LGBT, mereka lebih banyak manfaat daripada mudaratnya. Sarlito kemudian menyimpulkan bahwa LGBT semacam ini merupakan orang-orang yang tidak pernah lari dari fitrahnya, menerima orientasi dan identitas seksualnya, serta memaksimalkan potensi dirinya untuk kemaslahatan orang lain, atau dalam ilmu psikologi disebut homoseksual tipe sistonik (http://www.rappler.com/indonesia/122397lgbt-gaul-akademisi-kw-super, diakses 14 mei 2016).
CNN menampilkan berita ketika Mahkamah Agung telah membuat sebuah keputusan sah mengenai legalisasi pernikahan sejenis melalui breaking news. Dalam berita tersebut tampak Pamela Brown, reporter $C N N$ melaporkan bahwa kaum LGBT tampak sangat senang dan antusias menyambut legalisasi UU tersebut di Amerika Serikat. Selanjutnya dalam film Game on Thrones dan The Simpsons, kartun anak-anak tersebut memunculkan karakter gay. CNN membahasnya dalam sebuah acara CNN News Room dengan tajuk "Smithers Comes Out as Gay on the Simpsons" pada 5 April 2016.

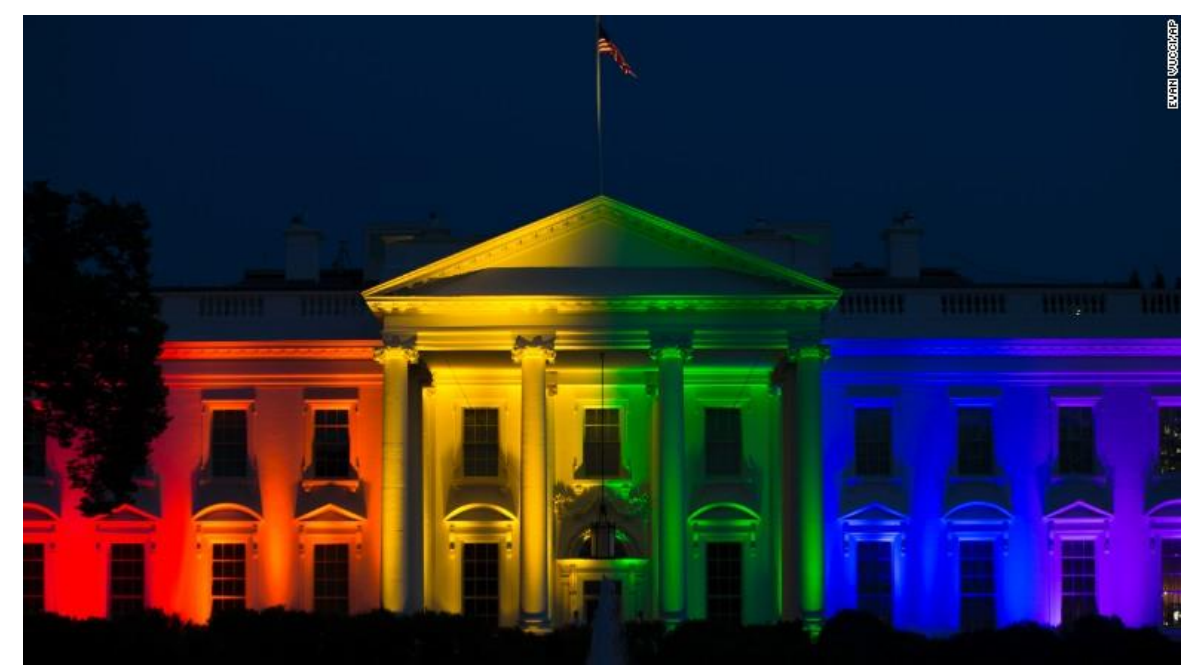

Gambar 2: Gedung Putih dengan Background Warna Pelangi

Sumber: http://edition.cnn.com/2015/06/26/politics/supreme-court-same-sex-marriageruling/Supreme Court rules in favor of same-sex marriage nationwide. Diakses 15 Mei 2016 
Lain halnya dengan Amerika Serikat, di Indonesia isu yang berkaitan dengan LGBT merupakan isu yang sensitif. Beberapa media elektronik nasional juga pernah membahasnya antara lain Kompas TV melalui program yang dipandu Rosianna Silalahi dalam "Program Khusus: LGBT Haruskah Dicemaskan?" yang ditayangkan pada Kamis 11 Februari 2016. Tayangan tersebut menghadirkan Pemred majalah
Gatra, aktivis LGBT dari Suara Kita, dan perwakilan dari Komnas Perempuan. Dalam tayangan tersebut dibahas tentang pernyataan Menristekdikti yang menyatakan bahwa LGBT tidak boleh masuk wilayah kampus yang dilatarbelakangi dengan keberadaan sebuah kelompok kemahasiswaan bernama SGRC yang berada di UI dan disinyalir merupakan kelompok LGBT.

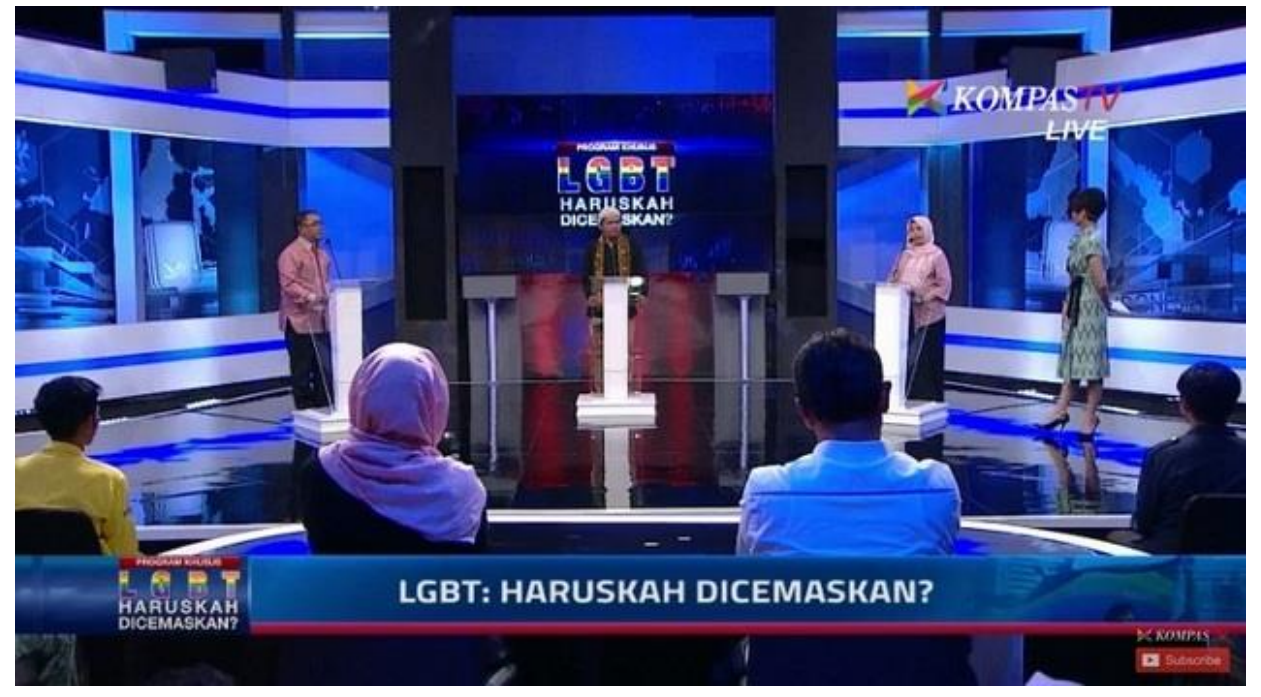

Gambar 3: Tayangan Program Khusus di Kompas TV

\section{Lembaga Swadaya Masyarakat (LSM)}

Menurut Bank Dunia, " NGOs as private organizations that pursue activities to relieve suffering, promote the interests of the poor, protect the environment, provide basic social services, or undertake community development". Secara umum LSM adalah sebuah komunitas dari masyarakat sipil yang membantu masyarakat lainnya untuk menyelesaikan sebuah persoalan yang berkaitan dengan lingkungan, HAM, kesehatan, SDA, dan lainnya yang tidak terkait dengan pemerintah dan beroperasi pada skala masyakarat, nasional, dan internasional. Beberapa LSM yang ada di Indonesia antara 
lain LSM pendamping LGBT berfocus pada beberapa bidang kegiatan seperti bidang hukum, kesehatan, dan HAM. Umumnya LSM ini terbentuk karena adanya beberapa persoalan yang ada di masyakarat seperti adanya tindakan diskriminasi dan kekerasan yang dialami oleh kaum LGBT, adanya stigma di masyarakat terkait kaum LGBT di bidang kesehatan terutama penularan HIV/AIDS serta permasalahan di bidang sosial lainnya.

Dengan munculnya beberapa LSM pendamping tersebut mempermudah kaum LGBT untuk mendapatkan pelayanan dan pendampingan ketika mendapatkan masalah di masyarakat. Dari tahun 1960-an hingga saat ini, LSM LGBT di Indonesia terus mengalami perkembangan, terlebih dengan adanya globalisasi dan kemajuan teknologi, beberapa hal yang dapat ditemukan bahwa LSM LGBT di Indonesia terus berkembang antara lain melalui forum-forum diskusi yang diselenggarakan baik secara terbuka ataupun tertutup, beberapa di antaranya: tanggal 6 - 9 November 2006 ada pertemuan 29 aktivis HAM di UGM, yang melahirkan "Prinsip-prinsip Yogyakarta" (The Yogyakarta Principles) yang mendukung keberadaan kaum LGBT dan menjadi rujukan perjuangan kaum LGBT di dunia khususnya di Indonesia. Muncul lembaga pro LGBT di Universitas Indonesia (UI), yang bernama Support Group and Resource Center on Sexuality Studies (SGRC) bulan Januari 2016. Saat ini, di Indonesia ada 2 jaringan nasional pendukung LGBT yaitu LSM yang bergerak di bidang hukum dan kesehatan, dan 119 kelompok LGBT di 28 provinsi (dari 34 provinsi) di Indonesia dengan jutaan pengikut. Atas sponsor UNDP dan USAID, pada 13 - 14 Juni 2013, LSM tersebut menggelar Dialog Komunitas LGBT Nasional Indonesia di Nusa Dua Bali. Selain itu juga dapat dilihat melalui berbagai kampanye lewat berbagai cara seperti: advokasi, konsultasi, film, aksi lapangan, seni, media massa, dan sebagainya, yang bertujuan untuk mendapatkan pengakuan di masyarakat sekitar secara lambat laun.

Beberapa merek dagang dunia mendukung atau pro LGBT, misalnya: Facebook, Whatsapp, LINE, dan Starbucks. Starbucks bahkan mendonasikan sebagian keuntungannya untuk mendukung kegiatan LGBT. Sedangkan, LINE yang mempunyai simbol atau emoticon pro LGBT beberapa waktu lalu juga sempat menghebohkan masyarakat Indonesia. Majalah kampus Boulevard ITB Edisi 57 (2007) pernah menurunkan laporan keberadaan komunitas homoseksual di kampus tersebut. 
Selanjutnya Studenta (2008), majalah sekelompok mahasiswa pecinta jurnalisme, juga mengungkap laporan adanya Ikatan Mahasiswa Homo (IMHO) di kampus IPB. Dari uraian tersebut, terlihat bahwa LSM pendukung LGBT yang ada di Indonesia memiliki peran penting bagi kegiatan kaum minoritas seperti LGBT. Hal ini terlihat pada beberapa pendampingan yang dilakukan dalam bidang kesehatan, advokasi, dan pendampingan lainnya.

\section{METODE PENELITIAN}

Penelitian ini menggunakan pendekatan kualitatif yaitu salah satu prosedur penelitian yang menghasilkan data deskriptif berupa ucapan atau tulisan dan perilaku orang-orang yang diamati (Bogdan dan Taylor, 1992). Pendekatan kualitatif diharapkan mampu menghasilkan uraian yang mendalam tentang ucapan, tulisan, dan atau perilaku yang dapat diamati dari suatu individu, kelompok, masyarakat, dan atau organisasi tertentu dalam suatu setting konteks tertentu yang dikaji dari sudut pandang yang utuh, komprehensif, dan holistik. Dalam penelitian ini pendekatan kualitatif digunakan dalam memperoleh data melalui narasumber yaitu Widodo Budidarmo dari LSM Arus Pelangi.
Metode yang digunakan adalah metode studi kasus sesuai dengan yang disampaikan oleh Robert K Yin (2008). Studi kasus digunakan sebagai suatu penjelasan komprehensif yang berkaitan dengan berbagai aspek seseorang, suatu kelompok, suatu organisasi, suatu program, atau suatu situasi kemasyarakatan yang diteliti, diupayakan dan ditelaah sedalam mungkin. Studi kasus juga memiliki pengertian berkaitan dengan penelitian yang terperinci tentang seseorang atau suatu unit sosial dalam kurun waktu tertentu.

Studi kasus menurut Yin (2008:18) adalah suatu inquiry empiris yang menyelidiki fenomena dalam konteks kehidupan nyata, bilamana; batas-batas antarfenomena dan konteks tak tampak dengan tegas dan di mana: multi sumber bukti dimanfaatkan. Sebagai suatu inquiry studi kasus tidak harus dilakukan dalam waktu yang lama dan tidak pula harus tergantung pada data etnografi atau observasi partisipan. Bahkan menurut Yin seorang peneliti bisa saja melakukan studi kasus yang valid dan berkualitas tinggi tanpa meninggalkan kepustakaan, tergantung pada topik yang akan diselidiki.

\section{HASIL PENELITIAN DAN PEMBAHASAN}


Berdasarkan Teori Disonansi Kognitif dapat dijelaskan bahwa pemberitaan tentang LGBT di berbagai media massa berimplikasi pada aktivitas LSM dalam bentuk dukungan sosial (social support). Dengan maraknya pemberitaan terkait LGBT di berbagai tempat (luar negeri dan dalam negeri) oleh media massa, tidak dapat dipungkiri hal ini berimplikasi pada aktivitas beberapa LSM. Mereka memiliki opini positif terhadap kaum LGBT selama tidak merugikan dan mengganggu kehidupan sosial masyarakat layak diperlakukan secara manusiawi dan mendapat dukungan sosial. Bentuk dukungan sosial yang dilakukan beberapa LSM seperti Arus Pelangi, Yayasan Intermedika, dan Yayasan Srikandi Sejati adalah memberikan pendampingan dalam konsultasi hokum dan pemeriksaan kesehatan.

LSM LGBT di Indonesia yang berdiri pada awal 1990-an, mulai bermunculan seiring meningkatnya liputan media tentang $H I V$ yang hampir selalu menyebutkan tentang pria homoseksual dan waria. Isu perilaku seks menyimpang yang dimuat di banyak media massa cenderung dikaitkan dengan kehidupan para kaum LGBT yang bertentangan dengan normanorma di masyarakat. Beberapa liputan kasus kekerasan fisik dan psikis (bullying) juga banyak diterima oleh kaum LGBT yang menimbulkan banyak pendapat pro dan kontra. Akibat maraknya liputan media massa terhadap kegiatan dan kasus-kasus terkait LGBT (perilaku seks menyimpang dan hukum) semakin membuat beberapa LSM tertarik untuk memberikan pendampingan. LSM tersebut tidak hanya baru berdiri di Indonesia namun juga ada yang berasal dari luar negeri dan membuka perwakilan di Indonesia.

Pemberitaan tentang LGBT dan isu sejenis secara langsung dan tidak langsung berimplikasi pada aktivitas LSM pendukung dan pendamping LGBT tersebut. Ramainya pemberitaan terutama yang berkaitan dengan perlakuan negatif yang diterima oleh LGBT memunculkan beberapa bentuk pembelaan dan perlindungan atas nama kemanusiaan dan HAM. Bentuk dukungan dan pembelaan tersebut tidak hanya diberikan oleh individu tetapi juga kelompok-kelompok seperti LSM. Semakin banyaknya pemberitaan terkait LGBT membawa implikasi pada LSM yang juga semakin berani muncul ke permukaan dalam memberikan dukungan sosial meskipun hal itu dianggap bertentangan dengan kebiasaan masyarakat pada umumnya. Secara garis besar, implikasi pemberitaan tersebut dibagi dua 
hal yaitu pemberitaan berimplikasi pada semakin banyak LSM pendukung dalam mempublikasikan kegiatannya di muka umum dan melahirkan kelompok-kelompok pendukung yang bercikal bakal pada LSMLSM baru yang mengatasnamakan pendukung dan pendamping LGBT.

Beberapa LSM yang memberikan dukungan sosial pada kaum LGBT seperti: Arus Pelangi memiliki program kegiatan seperti: kampanye yaitu kegiatan yang berisi sosialisasi hak-hak dasar manusia dan penghilangan tindakan diskriminatif pada kaum LGBT dan advokasi yaitu advokasi kasuistik dan advokasi kebijakan public. Advokasi kasuistik merupakan kegiatan penanganan hukum kasus-kasus yang menimpa kaum LGBT baik bersifat litigasi maupun non-litigasi. Advokasi kebijakan publik merupakan rangkaian upaya hukum terhadap semua kebijakan pemerintah yang diskriminatif misalnya penolakan terhadap Rancangan Undang-undang Anti Pornografi dan Pornoaksi (RUU-APP). Berikutnya adalah Yayasan Inter Medika dan Yayasan Srikandi Sejati yaitu LSM yang berfokus pada pendampingan atau penyuluhan kesehatan seperti penyakit menular seksual dan penanggulangan penyebaran virus HIV/AIDS pada kaum LGBT. Saat ini Yayasan Inter Medika bekerja sama dengan
Pemda DKI Jakarta dalam bidang kesehatan terutama yang berkaitan dengan HIV/AIDS di bawah koordinasi Komisi Penanggulangan HIV/AIDS Prov. DKI Jakarta bermitra juga dengan Dinas Kesehatan Prov. DKI Jakarta. Kerja sama ini mengarahkan kaum LGBT untuk melakukan Voluntary Counseling and Testing (VCT) dan penyembuhan/penanggulangan Infeksi Menular Seksual (IMS) di beberapa rumah sakit, klinik, dan Lapas di Jakarta.

\section{SIMPULAN}

Sejak awal munculnya komunitas LGBT di Indonesia mendapat tanggapan beragam dari lingkungan sosial yang diakui menganut etika ketimuran yang masih cukup kuat. Hal ini dianggap aneh, tabu, bahkan aib yang seharusnya dihilangkan atau dijauhkan dari kehidupan sosial. Sesuatu yang dianggap tidak wajar dan melanggar norma-norma sosial yang berlaku di masyarakat, terlepas dari apakah kaum LGBT tersebut memiliki kontribusi positif atau tidak dalam lingkungan sosialnya. Dalam kehidupan sosial secara umum pandangan, opini, dan stigma negative telah melekat pada kaum LGBT. Semakin

Banyaknya aktivitas komunitas LGBT tersebut tidak luput dari pemberitaan tentang isu-isu seputarnya cukup banyak 
mengambil porsi di media massa. Implikasi pemberitaan LGBT pada LSM adalah memunculkan bentuk dukungan sosial pada komunitas tersebut terutama dalam bidang hukum dan kesehatan. LSM berpendapat bahwa kaum LGBT layak mendapatkan dukungan sosial di tengah penolakanpenolakan yang mereka terima di lingkungan sosialnya. Teori Disonansi Kognitif yang berimplikasi dukungan sosial menjelaskan bahwa sesuatu yang dianggap kontradiktif atau tidak lazim di masyarakat seperti kaum LGBT masih layak mendapatkan opini positif seperti halnya yang dilakukan oleh LSM Arus Pelangi, Yayasan Intermedika, Yayasan Srikandi Sejati. Bentuk dukungan sosial yang diberikan oleh LSM tersebut adalah pendampingan dalam bidang perlindungan hukum maupun pendampingan kesehatan.

\section{DAFTAR PUSTAKA}

Berger, Peter L. \& Luckmann, Thomas. 1990. Tafsir Sosial Atas Kebudayaan: Risalah tentang Sosiologi Pengetahuan. Terjemahan The Social Construction of Reality: A Treatise in The Sociology of Knowledge oleh Hasan Basri. Jakarta: LP3ES

Bogdan, Robert C. dan Steven J. Taylor. 1992. Introduction to Qualitative Research Methotds: A Phenomenological Approach in the Social Sciences, alih bahasa Arief
Furchan, John Wiley dan Sons. Surabaya: Usaha Nasional.

Cangara, Hafied. 2009. Komunikasi Politik: Konsep, Teori, dan Strategi. Jakarta: Rajawali Press.

DeVito, Joseph A. 1996. Komunikasi Antarmanusia: Kuliah Dasar. Edisi ke 5. Jakarta: Professional Books

Foucault, Michael. 1997. The History of Sexuality. New York: Vintage Books.

Littlejohn, Stephen W. \& Karen A. Foss, 2011. Teori Komunikasi (Theories of Human Communication). Edisi 9. Jakarta: Salemba Humanika.

Mulyana, Deddy. 2008. Komunikasi Massa: Kontroversi, Teori, dan Aplikasi. Bandung: Widya Padjadjaran.

Rakhmat, Jalaluddin. 2007. Psikologi Komunikasi. Bandung: PT Remaja Rosdakarya

Sinyo. 2014. Anakku Bertanya tentang LGBT. Jakarta: PT Elex Media Komputindo Kompas - Gramedia.

Sudibyo, Agus. 2001. Politik Media dan Pertarungan Wacana. Yogyakarta: LKiS

Tommy Suprapto. 2009. Pengantar Teori dan Manajemen Komunikasi. Yogyakarta: Medpress.

\section{Jurnal}

Praptiningsih, Novi Andayani. Komunikasi Verbal dan Non Verbal dalam Jalinan Ikatan Committed Relationship pada Pasangan Gay. Jurnal Sociae Polites Volume 16 Nomor 1 Januari - Juni 2015

M. Farid Khakim dan Much. Imron. Https://Ejournal.Unisnu.Ac.Id/Jdeb/Article/ Viewfile/97/165 Disonansi Kognitif 
Mahasiswa dalam Memilih Progam Studi Manajemen di Stienu Jepara

Chendriawan, Tirsa Stephanie \& Ninik Sri Rejeki. http://ejournal.uajy.ac.id/4704/2/Jurnal\%20Tirsa_C ompatibility\%20mode.Pdf Upaya-Upaya Pengurangan Disonansi Kognitif Melalui Komunikasi Interpersonal

http://www.republika.co.id/berita/nasional /umum/15/06/29/nqp37b-sosiologeksistensi-lgbt-bisadirunut-sejakorde-baru Ramadhan, Bilal. (2015, 29 Juni), Sosiolog: Eksistensi LGBT Bisa Dirunut Sejak Orde Baru," diakses pada 7 mei 2016.

\section{Situs/Internet}

http://www.republika.co.id/berita/jurnalisme -warga/wacana/16/01/28/o1n41d336menelisikperjalanan-lgbt-di-indonesiapart1 Akbar, M. 2016, 28 Januari. "Menelisik Perjalanan LGBT di Indonesia," diakses pada 7 Mei 2016.

http://www.nytimes.com/interactive/2015/06 /26/us/changed-thinking-on-gaymarriage.html?_r=0, Einhorn, Catrin. 26 Juni 2015. How We Changed Our Thinking on Gay Marriage diakses 14 Mei 2016.

http://www.gatra.com/fokus-berita1/185468-arus-lgbt-masuk-kampus. Karni, Asrori S. 6 Februari 2016. Arus LGBT Masuk Kampus. diakses pada 14 Mei 2016.

http://www.sociology.kpi.ua/wpcontent/uploads/2014/06/Ranjit_Kuma r-Research_Methodology_A_Step-byStep_G.pdf Kumar. 1999

http://www.theglobeandmail.com/life/thehot-button/times-new-gay-marriage- covers-too-in-your-face-or-symbolsof-love/article10491076/ Mcginn, Dave. 2013. Time's new gay marriage covers: Too in your face or symbols of love? diakses 14 mei 2016.

http://nasional.sindonews.com/re ad/1086967/15/polemiklgbt-di-indonesia-sejak1973-1455971089

Ramdhani, Dian. (2016, 20 Februari),"Polemik LGBT di Indonesia Sejak 1973," diakses pada 7 mei 2016.

http://www.mustanir.com/201 6/01/28/menelisik-

perjalanan-kaum-lgbtdi-indonesia/ Rudi

Agung P. Jurnalis, (2016), $\quad$ "Menelisik Perjalanan Kaum LGBT di Indonesia," diakses pada 7 Mei 2016.

http://newmedia.org/what-is-newmedia.html. Socha, Bailey and Barbara Eber-Schmid. Defining New Media Isn't Easy. Diakes 15 Mei 2016.

http://www.rappler.com/indonesia/122397lgbt-gaul-akademisi-kw-super Yulius, Hendri. Published 9:19 AM, February 14, 2016. 'LGBT gaul' vs akademisi $K W$ super Tanggapan untuk kolom Sarlito Wirawan Sarwono di Majalah Gatra diakses 14 mei 2016.

http://www.rappler.com/indonesia/125064sejarah-gerakan-gay-indonesiahomoseksualitas Yulius, Hendri Published 7:30 AM, March 11, 2016 Sejarah gerakan gay di Indonesia: 
Perdebatan tentang homoseksualitas pada 1980-an, diakses 14 mei 2016.

http://www.komunikasipraktis.com/2014/08/ pengertian-media-baru-dan-jenisjenisnya.html Pengertian Media Baru dan Jenis-jenisnya. Diakes 15 Mei 2016.

http://www.alexa.com/siteinfo/nytimes.com NYTimes.com Info. diakses 1 Juni 2016.

http://internasional.kompas.com/read/2015/0 6/26/23073761/Mahkamah.Agung.Am erika.Legalkan.Pernikahan.Sesama.Jen is)

http://global.liputan6.com/read/2260668/per nikahan-sesama-jenis-dilegalkan-di-23negara-ini)

http://lifestyle.sindonews.com/read/1082855 /166/daftar-negara-yang-melegalkanpernikahan-sejenis-dan-lgbt1454594358. 